\title{
Improve Communication Quality by Understanding Customer Switching Behavior in China's Telecom Sector
}

\author{
Salman Awan, Yanxia Cheng \\ School of Management, Wuhan University of Technology, Wuhan, China \\ Email: awansalman@outlook.com,chengyanxia221@126.com
}

How to cite this paper: Awan, S. and Cheng, Y.X. (2016) Improve Communication Quality by Understanding Customer Switching Behavior in China's Telecom Sector. iBusiness, 8, 70-83.

http://dx.doi.org/10.4236/ib.2016.84008

Received: October 24, 2016

Accepted: November 11, 2016

Published: November 14, 2016

Copyright $\odot 2016$ by authors and Scientific Research Publishing Inc. This work is licensed under the Creative Commons Attribution International License (CC BY 4.0).

http://creativecommons.org/licenses/by/4.0/ (c) (i) Open Access

\begin{abstract}
This paper analyzes telecom consumer relationship by exploring customer switching behavior and classifying communication categories to support companies in planning applicable communication to thwart the consumer switching and improving consumer loyalty. Quantitative research is carried out by surveying 383 telecom consumers who have experienced the switching process. Findings uncover that telecom consumers selected distinct information methods before making switching decision. Active consumers prefer newsletter based on quality of service while passive consumers select newsletter largely based on competitive prices.
\end{abstract}

\section{Keywords}

Customer Switching Behavior, Telecom Customer Loyalty and Relationship Marketing Communication, Newsletters, Situational, Influential and Reactional Triggers, Switching Determinants

\section{Introduction}

Telecom enterprises world over are determined to create, retain and expand the customer base to boost their profits [1]. Communications are essential segment of this entire process from initiation till the completion and beyond. Consumers are gradually getting mindful of the service deals and accordingly it has become important for the enterprises to successfully communicate their services to the diverse kinds of consumers in tailored approach concurrently exploiting the existing written communication resources. It has previously been evidenced that communication's worth is considered essential in the consumer clubs as it can evidently influence the telecom consumer understandings' central features like price and experience [2]. 
Researchers focus on two dissimilar categories of telecom customers that are already revealed in earlier research; also their switching behavior is under investigation with the purpose to classify chosen communication forms by both kinds of consumers to support companies in planning tailored communications that could attract customers' particular behavior to stay with the companies for longer duration.

Understanding customer switching behavior is significant as it results in the loss of potential income stream. The overheads linked to obtaining new consumers, involving account setup, credit checks, and marketing expenditures, can be five times greater as compared to the expenses of consumer retention efforts [3] [4]. This concept means that when customer drops the current telecom company, then this service provider loses the potential revenue from that specific customer. And also this company has to acquire new customers so that it could earn the lost revenue from new customers. In this case, previously the company did not have to spend excessive money to entice the old customer; it just had to provide good service and cheaper price. But in order to gain new customer, company is required to spend heavy amount on advertisement so as to entice new customer, and the good quality and cheaper price offerings are additional expenses for the company. So eventually it is better for the company to minimize the advertisement cost by preventing the switching behavior of current customers. While the excellence of service, relationship, and general satisfaction are valuable for customer retention, what triggers consumers to shift from one service provider to another, is reasonably understudied [3] [5] [6].

Companies are required to focus on refining quality, value, and trustworthy consumer connections to triumph. That is precisely where this study supports companies in identifying the customer switching behavior by recognizing any of the three triggers i.e., influential, situational and reactional triggers followed by creating the tailored communication for both consumer groups, specifically, active and passive consumers, rendering to their corresponding approach and behavior, in the cultural setting of China [7] [8].

The telecom business has developed, accompanied by the persistent market growth and number of customers. Previously, telecom companies could be contingent on robust brand resources and loyal consumers; nevertheless, intense competition due to the entrance of several telecom companies into the market, has resorted to difficult existence of companies until they take essential measures.

As Roos and Gustafsson [9] explain that leading motive for consumer to switch a company is partial information. Triggers are the central starting facts that push consumer to reassess the relationship with existing company and this choice founded on already stated partial information that is present in subconscious of the consumer's mind instigates switch at a particular time. There are three sorts of triggers, reactional, situational and influential [9].

Roos, Edvardsoon, and Gustafsson [10] describe three types of triggers for switching behavior: situational triggers, influential triggers, and reactional triggers [4]. Situational triggers comprise demographic alterations; influential triggers comprise causes linked 
with the competitors' aggressive marketing attempts to expand their market share; and reactional triggers involve critical incidents in communications among consumers and brands. Grounded on this framework, they classify key switching determinants in numerous industries, involving banking, insurance, telecommunications, super-market, and social insurance [10]. As linked to "theory of reasoned action", these three triggers are observed as originating a deliberate switching process that later causes the switching behavior.

China has more than 800 million mobile phone users, where intense competition occurs amongst key mobile companies to obtain and maintain consumers. While Western researchers study different facets of customer switching behavior from diverse viewpoints, service excellence and customer switching behavior in China's market is relatively understudied [3] [5] [11] [12] [13] [14] [15]. Instant paper adjusts this research gap by providing an understanding of Chinese consumers' switching behavior [16] [17] [18] [19].

This paper consists of 10 segments. Following is the structure of this paper: Title, abstract, introduction, literature review, methodology, findings, discussion, implications for managers and conclusion, limitations and future research, and references.

\section{Customer Switching Behavior}

Telecom customers are attracted towards low prices, better service quality, social circle influence, and advertisement. Marketing researchers explore this area in detail in previous relevant studies. They have revealed "triggers" and "switching determinants" that cause customers to switch from one company to other. Moreover, based on the respective switching behavior, telecom customers have been identified as active or passive. These findings make it interesting for the service firms to understand, identify and relate their service offerings according to customer switching behavior, and consequently, companies can prevent customers from switching and hence revenue can be increased in cost effective manner.

Studies on service quality and service marketing uncover numerous explanations why consumers select any specific mobile company, ensuing in a wide range of literature on service quality, customer retention, and customer switching behavior [3] [5] [6] [20]. For instance, Parasuraman et al. [6] [20] offer a theoretical model of service quality in shape of a mechanism (SERVQUAL) for quantifying service quality. Although their enquiry roots exclusively on consumers in the West, their new research offers theoretical direction for the research of cross-cultural differentiations of service quality and links consumer behaviors in an international perspective. Studies demonstrate that observations of service quality, general contentment, and service encounters influence consumer loyalty in different settings [3] [21] [22]. Commonly studies in this area are centered on two key parts: (i) why consumers choose a mobile company, and (ii) what are the switching expenses and impediments.

In exploring why consumers select a mobile company, LaBarbera and Mazursky [23] employ a panel method to determine the significance of satisfaction and dissatisfaction 
in describing the behavior of repeat purchasers. They determine that satisfaction measure is a meaningful aspect for consumer loyalty development. Gonul, Peter, and Sugawara [24] state the correlation among purchase timing of households, repeat purchase, and the propensity to switch products and determine that distinctive product features impact the trend to switch: when the consumption interlude becomes lengthier, customers are further prone to switch, and when the consumers purchase the product frequently due to its importance, loyalty would endure. Athanassopoulos [25] studies the link among consumer contentment, service, and consumer loyalty and describes that consumer contentment is positively linked with averting consumer switching behavior in the banking business.

Various researchers study switching expenses and impediments and the subsequent impacts on consumers' choices to be loyal to a specific brand [26] [27] [28] [29] [30]. For instance, Kim, Klinger, and Vale (2003) describe switching expenses as the charges linked with shifting cellular companies due to several economic and psychological motivations [31]. Lam et al. (2004) split switching expenses into five sets, comprising money, effort, time, new technology, and uncertainty [14], whereas Bell et al. (2005) discuss that switching expenses contain sunk expenses, search expenses, and setup expenses [5]. Kim, Park, and Jeong (2004) link preceding studies on consumer preservation and consumer loyalty and state that switching impediments contain switching expenses, the desirability of substitutes, and social connections [32]. Jones et al. (2000) discuss that the damage of a personal connection with mobile company is a type of switching impediment [12], and Dowling and Uncles (1997) uncover that frequent flyer programs shape an economic switching impediment [33].

Though the literature on service marketing and service management indicates that several aspects are linked to service switching behavior, the direct implementation of these results in the international marketing and service management has restrictions since previous research centers on these questions in a Western setting, not directly on service switching in a global setting. Moreover, low service quality and discontent signify certain details why consumers switch service in the West, however they do not paint the complete picture. Convenience, price, and availability could improve consumer contentment and eventually impact consumers' behavioral motivations [3] [34]. Specifically, service breakdown might not cast the same impact as in the West in a collectivistic culture where consumers regularly enchant their own feelings and emotions (Hofstede, 2001), and therefore they are less prone to switch brands as a response to service breakdown [35]. Keaveney (1995) offers eight underlying constructs that could influence consumers to switch brands throughout service industries, comprising inconvenience, cost, service breakdown, competition, and subconscious elements [3].

Roos and Gustafsson [9] argue that consumers go through a thoughtful decision-making procedure before purchasing a brand's offering [9]. This concept has been demonstrated in the "theory of reasoned action" (Fishbein and Ajzen, 1975) which portrays that if a consumer aims to perform in a specific manner then s/he ultimately will do the same [36]. Moreover, Ajzen and Fishbein (2000) elucidate in the "expectan- 
cy-value model" stating that consumers undertake their subconscious recollections to choose a brand along with deliberating on the presently available information; that may be defined as active (deliberate decision making by consumer) or passive (brand advertisement influence on consumer decision making) [37]. Misinformation, prejudice and misjudgment are important concepts in this realm. Vickery and Morris (1948) define prejudice as "misjudgment" which means that consumer is inspired by brands' marketing efforts due to the incomplete information stored in consumers' mind [38].

Roos, Edvardsoon, and Gustafsson [10] describe three types of triggers for switching behavior: situational triggers, influential triggers, and reactional triggers. Situational triggers comprise demographic alterations; influential triggers comprise causes linked with the competitors' aggressive marketing attempts to expand their market share; and reactional triggers involve critical incidents in communications among consumers and brands. Grounded on this framework, they classify key switching determinants in numerous industries, involving banking, insurance, telecommunications, super-market, and social insurance [10]. As linked to "theory of reasoned action", these three triggers are observed as originating a deliberate switching process that later causes the switching behavior.

\subsection{Two Different Types of Telecom Customers}

There are two kinds of service consumers: active consumers and passive consumers [39]. Active consumers carefully obtain information regarding brands' services. This behavior elucidates active consumer's proclivity about forming long-term connections based on continuous information search process and then remaining loyal to the brand. That is why active consumers are naturally communicated by brands' marketing efforts. On the other hand, passive consumers are not as much prudent in obtaining information regarding brands' various offerings, let alone the consideration of marketing efforts directed towards them. This clarifies their penchant for minor concern for developing and maintaining the long-term connections with companies. Cioffi and Garner (1996) demonstrate that the major cause of such response from passive consumer is lack of their ability to compare and select between advertisements of diverse products of mobile companies [40]. Thus, prejudice overwhelms the diligence of the passive consumer's decision-making aptitude.

\subsection{Written Communication in Contemporary Customer Relationships}

Duncan and Moriarty (1998) describe communication as social deed of transmitting a message to others and creating its understanding in an eloquent style [41]. For example important consumers are influenced more efficiently by communication designs and express greater possibilities of loyalty regarding communication from companies [42]. In the previous studies, consumer switching behavior has been related to planning of applicable communication. For example in a relationship mapping technique SPAT [43], consumers' expressions in the connections are discovered to be related with their behavior. Sharma and Patterson [44] argue that articulate communication could gener- 
ate a sense of warmth along with fostering customer-to-business relations. Customer Relationship Management (CRM) is described as the field of collecting consumer's data to tailor the business plans according to certain consumer needs. It might support the cellular companies in establishing staunch connections with consumers by targeting advertising expertise, reduced quantity of consumer withdrawal and assuring provision of consumer needs that consequently could increase the consumer satisfaction and loyalty [45].

Raciti and Dagger [46] explain that aesthetical features of written communication should be considered before planning written communication for example writing style, paper quality, color, font, selection of the font style and use of the bold and italics. They also underscore the significance of paper quality and paper color, communication fittingness for example checking spelling and punctuation mistakes, size and simplicity of font and communicated messages' clearness for example sentences and related information on the consumer observation. To improve consumer loyalty, service providers could essentially engage these aesthetical aspects of written communication into the mechanisms as letters, brochures, newsletters and emails.

Merisavo and Raulas (2004) describe that newsletter communication has the essential purpose in direct marketing to inspire brand loyalty [47]. In this respect, newsletters, magazines and brand website are the instruments to support service providers by displaying the services to consumers on monthly, weekly and daily basis [48]. Newsletters are largely the communication means to support enterprises in planning tailored information comprising updates and entertainment [49]. Merisavo and Raulas (2004) explain that email is a recognized form of communication in this regard [47]. Major objectives for email usage in marketing are to disseminate marketing information concerning brands, products and services and to expand website traffic. Muller et al. (2008) identify that presently enterprises have strengthened the development of websites; by displaying communicating material alongwith related instruments such as email newsletters and magazine [48]. Mangold and Faulds (2009) describe that social media involves different instruments of online, word of mouth forums including blogs, twitter, enterprise sponsored discussion boards, consumer to consumer email, and social networking such as Facebook [50].

\section{Data and Methodology}

Researchers employ explorative research design with quantitative approach to conduct instant research study. As defined by Aaker et al. (2004), explorative design primarily examines previously unexplored research questions [51]. Researchers organized research questions through research guide in Roos (1999) that is amended for obvious requirements [43]. Later, data is collected via surveys and questionnaires. After data collection, researchers create different categories by decoding and studying the data, to trace the repetitions.

By surveying 383 telecom customers in Wuhan, China, who have previously switched telecom company due to some specific reason, researchers witness the actions in which 
customers relate their telecom relationship to the tangible behavior. Customers' ages range from 18 year old to 45 year old. Most of the respondents belong to millennial age group. On the basis of previous research study, researchers devise two kinds of newsletters communications, one for active customers and the other for passive customers. These two kinds of newsletters are part of the standard survey questionnaire, comprising 30 questions and consequently customers' options are documented. First part of questionnaire comprises of open-ended questions and 5-point likert scale questions ranging from "Not at all important" to "extremely important". Later, researchers correlate the inferences from primary research to the theoretical background and learn the forms of communication for active and passive consumers consistent with their particular switching behavior and communication inclination. Questionnaire is primarily based on 6 sections. These sections are mentioned as follows: background information, customer relationship with current service provider, customer relationship with previous service provider, nature of products and services used in the package, conclusion, and communication testing.

Hague et al. (2004) define coding as forming code frame which involves classes of information assembled together in individual heads; in order to examine the information drawn via surveys [52]. Classes in the code frame are formed by demarcating important features from literature and likewise by information collected through surveys for insistence switching determinants were classified before the applicable trigger division.

Microsoft excel is employed for quantitative data analysis and all the data is analysed for frequency and cross tabulations and percent of all the questions to interlink with each other.

Researchers design two kinds of newsletters, active newsletter and passive newsletter. switching determinants and triggers establish the active and passive behavior of consumers, which are used to design active and passive newsletters to persuade the separate kinds of consumers. Roos and Gustafsson [9] define that communicating efficiently to active and passive consumers are made conceivable when variances between active and passive consumers are uncovered in research studies [9].

Following is an excerpt from the "Active Newsletter" emphasizing quality service and rich information about innovative services:

"China Unicom presents a new flexible subscriptions package that you can change at any time. You can use the one month package for call, SMS/MMS and internet surfing (20 GB included). You also get free access to our super-fast surfing zones. If you prefer, you can increase the package during the period by one or more of the options. When you do not need the package further, you can return to your normal monthly package. Right now it includes free music download from iTunes, and a revolutionary, Music System. Play and control your music in every room with your smartphone or smart pad."

Following is the passive newsletter emphasizing on cheaper prices instead of service quality: 
"China Unicom presents a new subscriptions package for 24 months, you get the first 6 months only for half monthly fee. With this service, you can call for 0 RMB per minute and send free SMS/MMS to all customers of other telecom companies."

Reliability of the present study means that despite the repetition of data collection process in the same research settings, identical outcomes would be produced, thus guaranteeing its long-term credibility (Jacobsen, 2002) [53]. Data fittingness is also established by receiving the initially planned information from customers, if a respondent could not understand any part of the questionnaire, then questions are rearticulated in more plausible fashion. A standard questionnaire is utilized to carry out all the surveys. Merely agreeable and eligible respondents are selected for the surveys as those respondents who have switched telecom company at least once, furthermore respondents are asked to be outspoken.

\section{Findings}

Table 1 encloses the empirical data assembled by surveys. Through coding, all responses in questionnaires are allocated to the appropriate group.

There are 3 telecom companies competing for market share, namely, China Mobile, China Telecom and China Unicom. 134 customers are currently using China Unicom, 139 customers are using China Mobile and 100 customers are using China Telecom. 168 out of 383 are active consumers while remaining 215 are passive consumers.

Likewise, 223 influential, 103 situational and 57 reactional triggers are witnessed. 3 forms of triggers and 5 kinds of switching determinants generally drive consumers towards switching course thus it is vital to evaluate these two factors in association with each other.

Most suggestively motivating component towards switching is exposed as "price" as 97 consumers state it as pivotal feature owing to lesser buying power therefore it is presented as influential passive trigger. "Suggested" switching determinant produced by

Table 1. Empirical data from surveys.

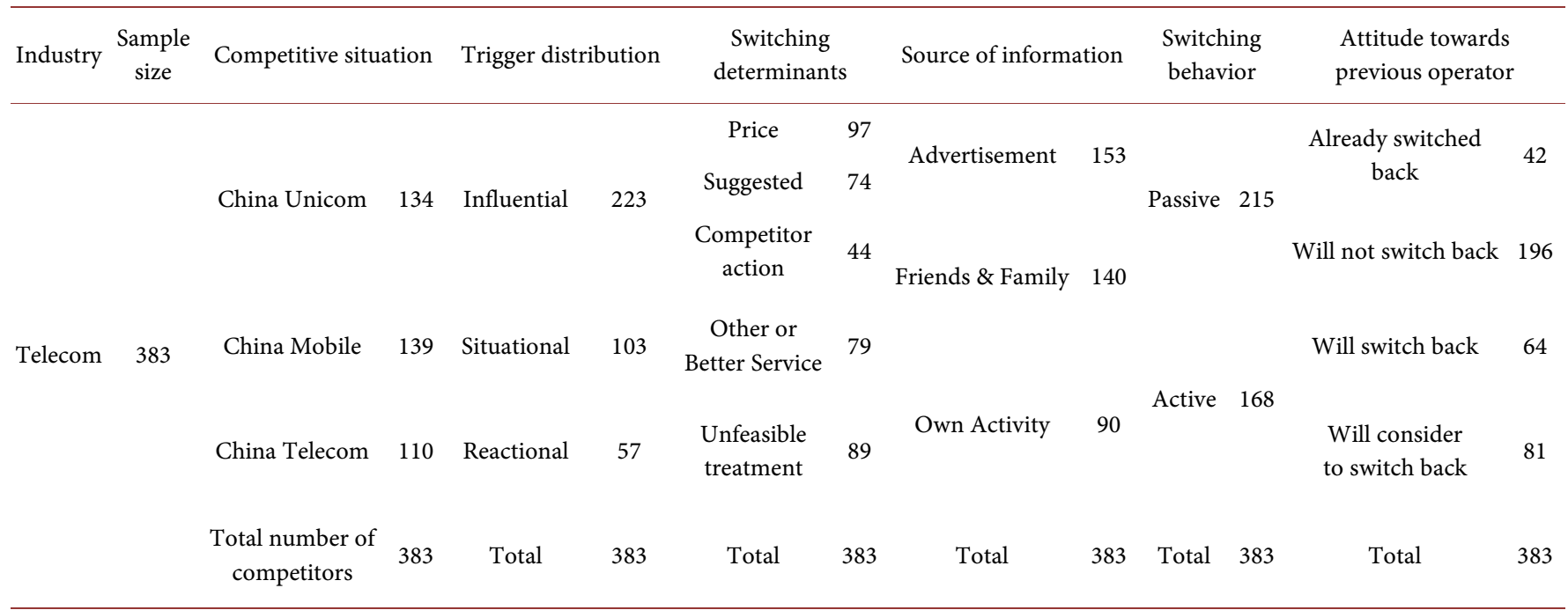


friends and family is seen as exceptional owing to the greater talk occurrence between social circle; 74 consumers believe it as the most important facet. This determinant is segment of influential active trigger since consumer robustly explored numerous obtainable substitutes following idea from social circle. Publicity marketing actions of competitors persuade 44 consumers who are swayed by influential passive trigger due to their deficiency of active exploration participation and instant substituting action based on publicity events of competitor. Untimely reply from company staffs sway 79 consumers to switch. Other/better services draw 89 customers' responsiveness due to perfect signal coverage (Figure 1).

"Source of information" labels consumer's route concerning switching in the course of trigger occurrence thus raising its significance in the switching behavior. Consumers receive the information mainly by advertisement, friends \& family and/or own activity.

140 consumers receive the information sourcing the switching by family and friends. Advertisements produce triggers in 153 consumers' minds. Just 90 consumers state the cause of trigger as their own activity.

Outcomes of communication testing disclose that 197 consumers like passive newsletter whereas the other 186 consumers like active newsletters (Figure 2).

Gustafsson et al., (2004) reinforce these outcomes by emphasizing the propensity of telecom consumers to validate passive behavior by desiring price as an effect of rising competitive marketing strategies [2].

\section{Discussion}

Active consumers evidently prefer communication grounded on service quality information, comprising company's various innovative packages, unrelatedly of prices. They frequently explore comprehensive information by their own initiative, in place of only becoming persuaded by social circle's thoughts or competitors' advertising tactics. Their key motives for switching are recognized as obtainability of improved services and encountering unfeasible management by the telecom company's staffs. So, companies

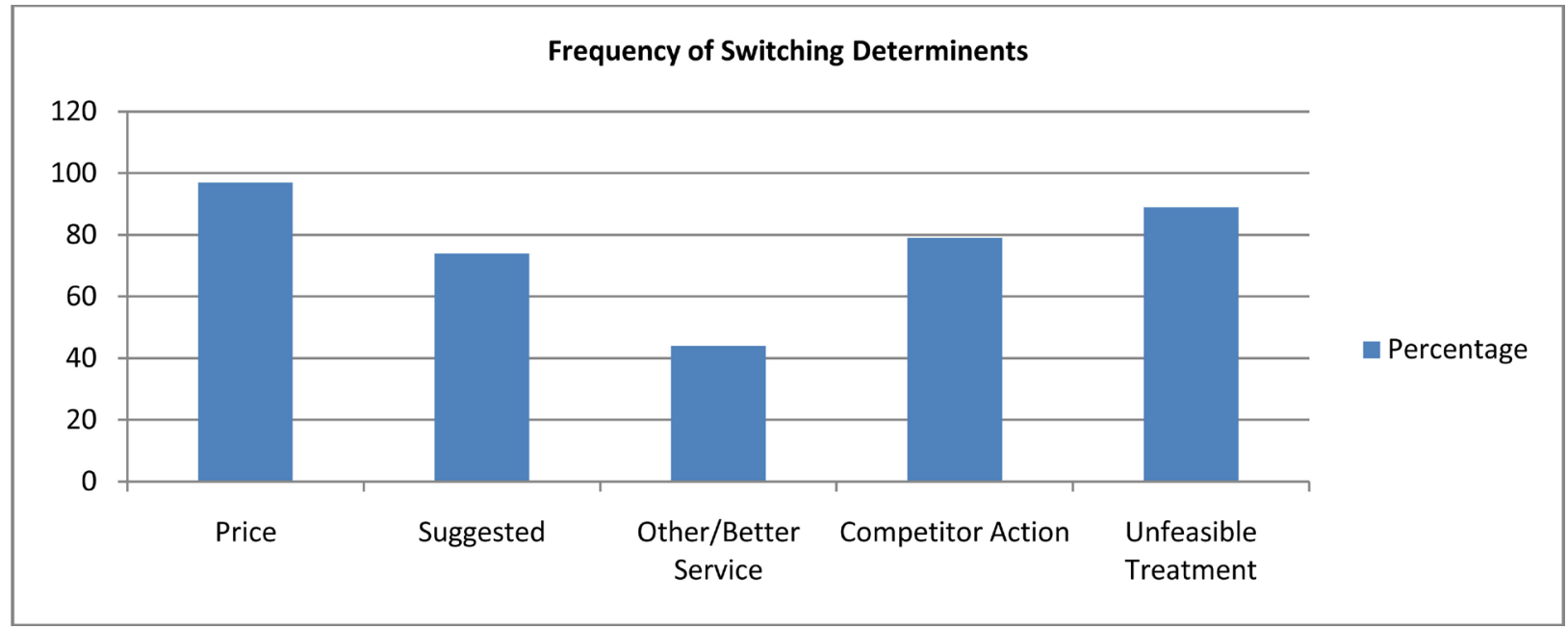

Figure 1. Frequency of switching determinants. 


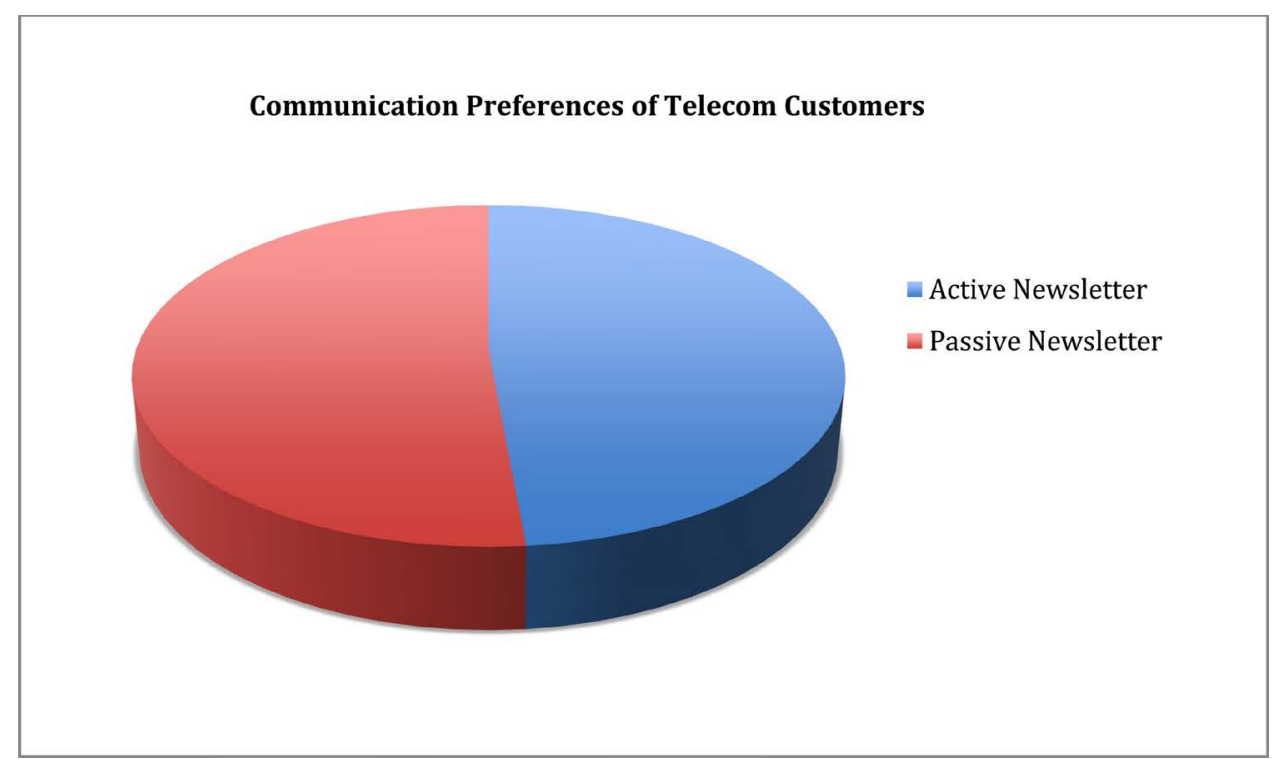

Figure 2. Communication preferences of telecom customers.

are required to interact active consumers concerning cutting-edge subscriptions, and guarantee best conduct and service quality. Active consumers also select active newsletter because they plan to assess numerous options promoted by diverse telecom operators.

Roos and Gustafsson [9] term passive consumers as not being observant to the publicity material focused regarding them and they should be often communicated, additionally this notion is likewise reinforced by the results of current analysis as passive consumers reply that they are mostly persuaded by price feature and also by recommendation of friends and family to make switching decision; so to positively accomplish relationship with passive consumers, telecom operators are required to incorporate marketing communication focusing on price that ought to be regularly communicated across consumers' friends and family [9].

In communication testing, 58 consumers are originally discovered as active in questionnaire processing but they selected passive newsletter since they prefer to receive the information about special prices. Roos and Gustafsson [9] classify that influential trigger with price as switching determinant might indicate unsteady prospective consumer relationship with existing telecom operator while situational trigger with price as switching determinant could indicate a durable prospective consumer relationship [9].

\section{Conclusion and Implications for Managers}

Propositions of this paper communicate the method to avert the triggers from occurrence. Current analysis provides the prospect to the telecom enterprises of growing the long-term consumer reliability by communicating and classifying the active and passive consumers. Thought process of consumer switching management, founded on triggers, omens significant results for telecom consumer relationships [9]. To regulate this switching development, telecom enterprises are required to observe the switching de- 
terminants exposed in current study, by examining and using the several causes of information to customers, that are likewise presented in this research as utilized by consumers to acquire the vital information for centering their switching choice, through tailored written communication for example selected by active and passive consumers in communication testing stage.

\section{Limitations and Future Research}

As preliminary determination to connect triggers and switching determinants with the precise form of written communication, scholars confront challenges in designing research instrument so upcoming research could cultivate developed research instrument to estimate the successful communication forms and descriptions. Research might also define the proportion of active and passive consumers to adopt the corresponding communication quotient.

\section{References}

[1] Ferguson, R. and Brohaugh, B. (2008) Telecom's Search for the Ultimate Customer Loyalty Platform. Journal of Consumer Marketing, 25, 314-318. http://dx.doi.org/10.1108/07363760810890543

[2] Gustafsson, A., Roos, I. and Edvardsson, B. (2004) Customer Clubs in a Relationship Perspective: A Telecom Case. Managing Service Quality, 14, 157-168. http://dx.doi.org/10.1108/09604520410528581

[3] Keaveney, S.M. (1995) Customer Switching Behavior in Service Industries: An Explorative Study. Journal of Marketing, 59, 71-82. http://dx.doi.org/10.2307/1252074

[4] Peters, T. (1988) Thriving on Chaos. Alfred A. Knopf, New York.

[5] Bell, S.J., Auh, S. and Smalley, K. (2005) Customer Relationship Dynamics: Service Quality and Customer Loyalty in the Context of Varying Levels of Customer Expertise and Switching Costs. Journal of Marketing Science, 33, 169-183. http://dx.doi.org/10.1177/0092070304269111

[6] Parasuraman, A., Zeithaml, V.A. and Berry, L. (1988) SERVQUAL: A Multiple-Item Scale for Measuring Consumer Perceptions of Service Quality. Journal of Retailing, 64, 12-40.

[7] Song, L.Z., Song, M. and Di Benedetto, C.A. (2009) A Staged Service Innovation Model. Decision Sciences, 40, 571-599. http://dx.doi.org/10.1111/j.1540-5915.2009.00240.x

[8] Uncles, M. and Kwok, S. (2009) Patterns of Store Patronage in Urban China. Journal of Business Research, 62, 68-81. http://dx.doi.org/10.1016/j.jbusres.2008.01.002

[9] Roos, I. and Gustafsson, A. (2011) The Influence of Active and Passive Customer Behavior on Switching in Customer Relationships. Managing Service Quality, 21, 448-464. http://dx.doi.org/10.1108/09604521111159771

[10] Roos, I., Edvardsoon, B. and Gustafsson, A. (2004) Customer Switching Patterns in Competitive and Noncompetitive Service Industries. Journal of Service Research, 6, 256-271. http://dx.doi.org/10.1177/1094670503255850

[11] Burnham, T.A., Frels, J.K. and Mahajan, V. (2003) Consumer Switching Costs: A Typology, Antecedents, and Consequences. Journal of the Academy of Marketing Science, 31, 109126. http://dx.doi.org/10.1177/0092070302250897

[12] Jones, M.A., Mothersbaugh, D.L. and Beatty, S.E. (2000) Switching Barriers and Repurchase 
Intentions in Service. Journal of Retailing, 76, 259-274.

http://dx.doi.org/10.1016/S0022-4359(00)00024-5

[13] Kerin, R.A., Varadarajan, P.R. and Peterson, R.A. (1992) First-Mover Advantage: A Synthesis, Conceptual Framework, and Research Propositions. Journal of Marketing, 56, 33-52.

http://dx.doi.org/10.2307/1251985

[14] Lam, S.Y., Shankar, V., Erramilli, M.K. and Murthy, B. (2004) Customer Value, Satisfaction, Loyalty, and Switching Costs: An Illustration from a Business-to-Business Service Context. Journal of the Academy of Marketing Science, 32, 293-311. http://dx.doi.org/10.1177/0092070304263330

[15] Lieberman, M.B. and Montgomery, D.B. (1988) First-Mover Advantages. Strategic Management Journal, 9, 41-58. http://dx.doi.org/10.1002/smj.4250090706

[16] Laroche, M. (2011) Globalization, Culture, and Marketing Strategy: Introduction to the Special Issue. Journal of Business Research, 64, 931-933.

http://dx.doi.org/10.1016/j.jbusres.2010.11.014

[17] Luo, X. and Hassan, M. (2009) The Role of Top Management Networks for Market Knowledge Creation and Sharing in China. Journal of Business Research, 62, 1020-1026. http://dx.doi.org/10.1016/j.jbusres.2008.05.004

[18] Song, M., Di Benedetto, A. and Song, L.Z. (2000) Pioneering Advantage in New Service Development: A Multi-Country Study of Managerial Perceptions. Journal of Product Innovation Management, 17, 378-392. http://dx.doi.org/10.1016/S0737-6782(00)00054-0

[19] Song, M., Di Benedetto, A. and Zhao, Y.L. (1999) Pioneering Advantages in Manufacturing and Service Industries: Empirical Evidence from Nine Countries. Strategic Management Journal, 20, 811-836.

http://dx.doi.org/10.1002/(SICI)1097-0266(199909)20:9<811::AID-SMJ52>3.0.CO;2-\#

[20] Parasuraman, A., Zeithaml, V.A. and Berry, L. (1985) A Conceptual Model of Service Quality and Its Implications for Future Research. Journal of Marketing, 49, 41-50. http://dx.doi.org/10.2307/1251430

[21] Kelley, S.W., Hoffman, K.D. and Davis, M.A. (1993) A Typology of Retail Failures and Recoveries. Journal of Retailing, 69, 429-452. http://dx.doi.org/10.1016/0022-4359(93)90016-C

[22] Rust, R.T. and Zahorik, A.J. (1993) Customer Satisfaction, Customer Retention, and Market Share. Journal of Retailing, 69, 193-215. http://dx.doi.org/10.1016/0022-4359(93)90003-2

[23] LaBarbera, P.A. and Mazursky, D. (1983) A Longitudinal Assessment of Consumer Satisfaction/Dissatisfaction: The Dynamic Aspect of the Cognitive Process. Journal of Marketing Research, 20, 393-404. http://dx.doi.org/10.2307/3151443

[24] Gonul, F.F., Peter, T.L. and Sugawara, T. (1996) Joint Estimates of Purchase Timing and Brand Switch Tendency: Results from a Scanner Panel Data Set of Frequently Purchased Products. Canadian Journal of Economics, 29, 501-504. http://dx.doi.org/10.2307/136096

[25] Athanassopoulos, A.D. (2000) Customer Satisfaction Cues to support Market Segmentation and Explain Switching Behavior. Journal of Business Research, 47, 191-207. http://dx.doi.org/10.1016/S0148-2963(98)00060-5

[26] Chen, P.Y. and Hitt, L.M. (2002) Measuring Switching Costs and the Determinants of Customer Retention in Internet-Enabled Business: A Study of the Online Brokerage Industry. Information Systems Research, 13, 255-274. http://dx.doi.org/10.1287/isre.13.3.255.78

[27] Colgate, M. and Lang, B. (2001) Switching Barriers in Consumer Markets: An Investigation of the Financial Services Industry. Journal of Consumer Marketing, 18, 332-347. http://dx.doi.org/10.1108/07363760110393001 
[28] Dick, A.S. and Basu, K. (1994) Customer Loyalty: Toward an Integrated Conceptual Framework. Journal of the Academy of Marketing Science, 22, 99-113. http://dx.doi.org/10.1177/0092070394222001

[29] Murray, K.B. (1991) A Test of Service Marketing Theory: Consumer Information Acquisition Activities. Journal of Marketing, 55, 20-38. http://dx.doi.org/10.2307/1252200

[30] Nilssen, T. (1992) Two Kinds of Consumer Switching Costs. The Rand Journal of Economics, 23, 579-589. http://dx.doi.org/10.2307/2555907

[31] Kim, M., Klinger, D. and Vale, B. (2003) Estimating Switching Costs: The Case of Banking. Journal of Financial Intermediation, 12, 25-56. http://dx.doi.org/10.1016/S1042-9573(02)00005-0

[32] Kim, M., Park, M.C. and Jeong, D.H. (2004) The Effects of Customer Satisfaction and Switching Barrier on Customer Loyalty in Korean Mobile Telecommunication Service. Telecommunication Policy, 28, 145-159. http://dx.doi.org/10.1016/j.telpol.2003.12.003

[33] Dowling, G. and Uncles, M. (1997) Do Customer Loyalty Programs Really Work? Sloan Management Review, 38, 71-82.

[34] Cronin, J.J. and Taylor, S.A. (1992) Measuring Service Quality: A Reexamination and Extension. Journal of Marketing, 56, 55-68. http://dx.doi.org/10.2307/1252296

[35] Hofstede, G. (2001) Culture's Consequences: Comparing Values, Behaviors, Institutions, and Organizations across Nations. Sage, Thousand Oaks.

[36] Fishbein, M. and Ajzen, I. (1975) Belief, Attitude, Intention and Behavior: An Introduction to Theory and Research. Addison-Wesley, Reading.

[37] Ajzen, I. and Fishbein, M. (2000) Attitudes and the Attitude-Behavior Relation: Reasoned and Automatic Processes. European Review of Social Psychology, 11, 1-33. http://dx.doi.org/10.1080/14792779943000116

[38] Vickery, W.E. and Morris, E.O. (1948) A Redefinition of Prejudice for Purposes of Social Science Research. Human Relations, 1, 419-428. http://dx.doi.org/10.1177/001872674800100402

[39] Roos, I., Gustafsson, A., Edvardsson, B., et al. (2011) SPAT (Switching Path Analysis Technique)-A Method for Understanding Switching Paths and Future Behavior. Advances in Service Quality, Innovation and Excellence, Ithaca.

[40] Cioffi, D. and Garner, R. (1996) On Doing the Decision: Effects of Active versus Passive Choice on Commitment and Self-Perception. Personality and Social Psychology Bulletin, 22, 133-147. http://dx.doi.org/10.1177/0146167296222003

[41] Duncan, T. and Moriarty, S.E. (1998) A Communication Based Marketing Model for Managing Relationships. Journal of Marketing, 62, 1-13. http://dx.doi.org/10.2307/1252157

[42] Sun, C.B., Wilcox, R. and Zhu, T. (2008) Ignoring Your Best Customer? An Investigation of Customer Satisfaction, Customer Retention and Their Financial Impact. Journal of Relationship Marketing, 6, 87-116. http://dx.doi.org/10.1300/J366v06n03_05

[43] Roos, I. (1999) Switching Processes in Customer Relationships. Journal of Service Research, 2, 68-85. http://dx.doi.org/10.1177/109467059921006

[44] Sharma, N. and Patterson, P.G. (1999) The Impact of Communication Effectiveness and Service Quality on Relationship Commitment in Consumer Professional Services. The Journal of Services Marketing, 13, 151-170. http://dx.doi.org/10.1108/08876049910266059

[45] Tohidinia, Z. and Haghighi, M. (2011) Predictors and Outcomes of Relationship Quality: A Guide for Customer-Oriented Strategies. Business Strategy Series, 12, 242-256. http://dx.doi.org/10.1108/17515631111166889 
[46] Raciti, M. and Dagger, T. (2010) Embedding Relationship Cues in Written Communication. Journal of Services Marketing, 24, 103-111. http://dx.doi.org/10.1108/08876041011031082

[47] Merisavo, M. and Raulas, M. (2004) The Impact of E-Mail Marketing on Brand Loyalty. Journal of Product and Brand Management, 13, 498-505. http://dx.doi.org/10.1108/10610420410568435

[48] Muller, B., Flores, L., Agrebi, M., et al. (2008) The Branding Impact of Brand Websites: Do Newsletters and Consumer Magazines Have a Moderating Role. Journal of Advertising Research, 48, 465-472. http://dx.doi.org/10.2501/S0021849908080471

[49] Brondmo, H.P. (2000) The Engaged Customer: The New Rules of Internet Direct Marketing. HarperCollins Publishers, New York.

[50] Mangold, W.G. and Faulds, D.J. (2009) Social Media: The New Hybrid Element of the Promotion Mix. Journal of Business Horizons, 52, 357-365. http://dx.doi.org/10.1016/j.bushor.2009.03.002

[51] Aaker, D., Kumar, V. and Day, G. (2004) Marketing Research. John Wiley \& Sons Inc., New York.

[52] Hague, P.N., Hague, N. and Morgan, C. (2004) Market Research in Practice: A Guide to the Basics. Kogan Page Publishers, London.

[53] Jacobsen, D.I. (2002) Vad, hur och varför: Om metodval i företagsekonomi och andra samhällsvetenskapliga ämnen. Lund Universitetet, Lund.

Submit or recommend next manuscript to SCIRP and we will provide best service for you:

Accepting pre-submission inquiries through Email, Facebook, LinkedIn, Twitter, etc. A wide selection of journals (inclusive of 9 subjects, more than 200 journals)

Providing 24-hour high-quality service

User-friendly online submission system

Fair and swift peer-review system

Efficient typesetting and proofreading procedure

Display of the result of downloads and visits, as well as the number of cited articles

Maximum dissemination of your research work

Submit your manuscript at: http://papersubmission.scirp.org/

Or contact ib@scirp.org 